\title{
Weather Wanderings
}

Mindy Blaise ${ }^{1}$,Tonya Rooney², and Jo Pollitt ${ }^{1}$

${ }^{1}$ Edith Cowan University, Perth, Australia and ${ }^{2}$ Australian Catholic University, Perth, Australia

\section{Acknowledgements}

We would like to acknowledge that this project was funded by the Social Sciences and Humanities Research Council, Canada, through a Partnership Development Grant, and the Edith Cowan University Vice Chancellor's Professorial Research Fellowship. 
We would like to acknowledge that our weather wanderings take place on and with Ngunnawal Country, in what is also now known as Canberra, in the Australian Capital Territory. We draw inspiration from Affrica Taylor's (2013) scholarship, which proposes a common worlds framing (borrowing from Bruno Latour, 2004) that recognises childhood as messy and implicated, situated and differentiated, and entangled within diverse publics. Building on the critical walking scholarship of Stephanie Springgay and Sarah E. Truman (2018), our weather wanderings are part of a broader political project that involves walkingwith place and other species as a strategy to respond to the social and ecological times that children are a part of, not separate from (Blaise, 2017; Blaise and Hamm, 2019; Blaise and Rooney, 2019; Rooney, 2018, 2019; Taylor and Rooney, 2016). In particular, our work interferes with the dominant discourse of developmentally appropriate practices that regulate children's bodies and their environments. More specifically, our weather work ruptures and intervenes into the stronghold that child development has on the field of early childhood education.

We propose weather wanderings as a critical and postdevelopmental intervention (Blaise, 2010) into a developmentally appropriate or child-centred approach to walking. A developmentally appropriate approach emphasises an autonomous, white, able-bodied, middle-class, and developing boy child that discovers and explores the natural world as an external thing to 'know' and control. A developmental approach is concerned with discovery and conquest; legacies of settler colonialism. All too often, in early childhood education, when (and if) children and teachers leave the preschool to go on walks, these quickly turn into destination- and education-focused events that are full of regulation and control (Springgay \& Truman, 2019). During these kinds of walks, teachers attend to children's behaviour, safety, and physical capacity, all understood as developing along a linear trajectory of progress towards being able to navigate the world as a capable and competent adult. Planning for a child-centred weather walk usually begins with a large group discussion about the weather as external to a child's body and external to the learning space. Weather is always outside. Children might be asked to recall what the weather felt like on their way to preschool or to look outside the window to determine if it is 'sunny' or 'rainy'. Often, if these weather conditions are considered to cause discomfort (it's too windy, it's too cold, it's too hot, etc.) then a decision is made to stay inside.

In contrast, we re-think both walking as practice and weather as context to propose weather wanderings as a more-than-human pedagogical practice. In doing so, children are viewed as always on the move with-weather, and where the discomforts of weather are seen as generative and always entangled, rather than something to avoid. We resist thinking of the weather as simply an external force that acts upon human bodies, because this fails to acknowledge children's entanglements with the weather world (Ingold, 2015) and denies the implication of certain human actions, such as in the devastating effects of Anthropogenic climate change. Rather, we are reminded by Astrida Neimanis and Rachel Walker's (2014) early weather scholarship that we are all 'weather bodies.' We take from this the idea that not only are children weather bodies, but mice, rabbits, anthills, puddles, grass, trees, rocks, chainsaws, sawdust and dirt are also weather bodies. Our photographs reveal the inseparability of weather bodies that are each weathered differently and yet at the same time are weathering together complex entangled world(s).

We think of our walks as wanderings; this means that bodies flow and meander with weather and generate new wanderings. Weather wanderings expand on Tonya Rooney's $(2018 ; 2019)$ weather worlding inquiries with children. Weather wanderings interfere with the developmental child because they shift our thinking beyond focusing exclusively on the 
human child body, and what they are learning or sensing, to witness the intermingling of weather with place, animals and plants across time and space. Attuning to weather elements (precipitation, humidity, temperature, pressure, cloudiness, and wind) is part of weather wanderings but not with the goal of encouraging scientific thinking and problem-solving about weather. Instead, interest is paid to the various ways weather elements mingle with an array of human and more-than-human bodies as part of all learning. While wandering, attention is paid to the shaping and shifting of landforms and habitats that belong to millions of species and times other than our own. Weather wanderings are an invitation to wonderwith weather; atmospheres and elements move through children's bodies while they move with more-than-human others in worlds that are being shaped by care and carelessness.

We wander: not to watch children progress to the next developmental milestone, nor to see them navigate a weather world where they are at the centre, but, rather, to wonder with unfolding, lively and, sometimes, unruly weathering-with relations. Our weather wanderings are a type of 'slowing down' that Isabelle Stengers (2018) advocates. It renders us attentive (Stengers, 2015), and opens new pathways and possibilities for coming to know the world.

The following photos show how weather wanderings are generative of worldly wonderings. These show a pedagogical practice that activates attunements to the interconnections within the worlds we wander through.

\section{Weather Wanderings}

Wrapped up in woollen beanies we run along, our skin breathing in the cold winter air and feet crunching over a dry grassy hillside. Clouds hover. Smooth, damp sticks invite our grasp and help us to notice.

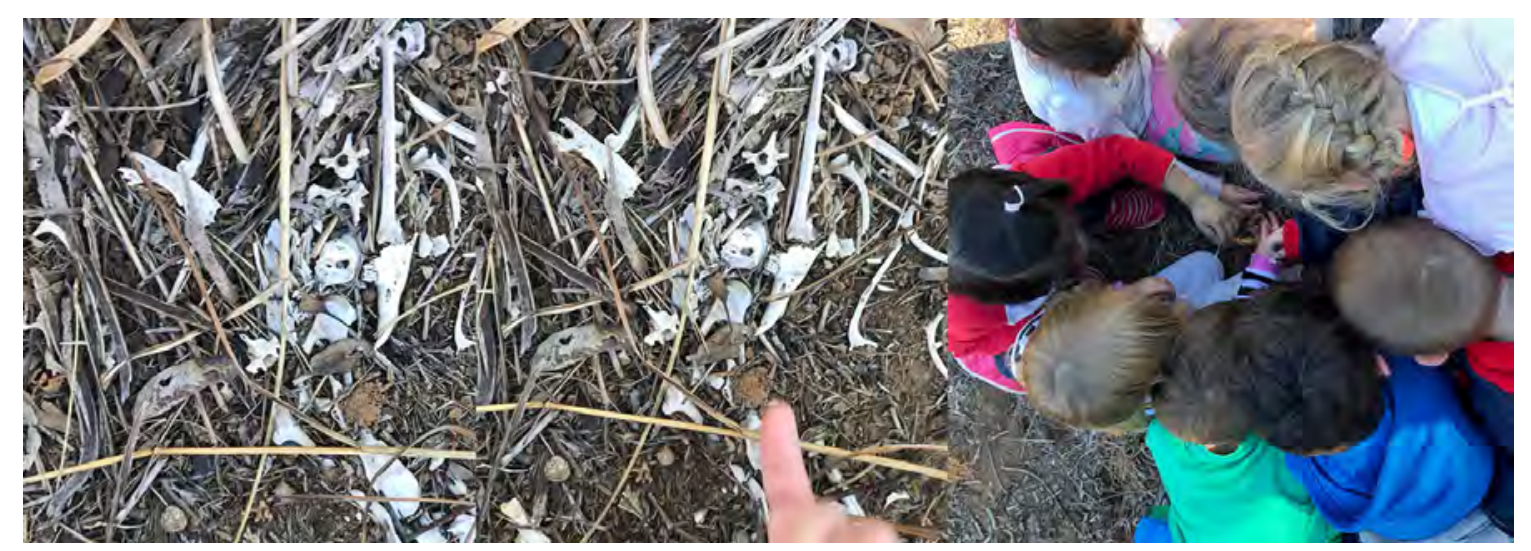

Figure 1: Wandering. Photo credit: Authors.

\section{Wandering-with Weathered Bones}

Tiny bones weathering see us winding through unexpected pathways and walking-with multiple histories. Weathered bones stop us, forcing us to pause, bend down, and take notice. "Where did they come from?" "What did they come from?" Temporalities stretch long behind and far ahead. A weather confluence of bones, breath and bending bodies. 


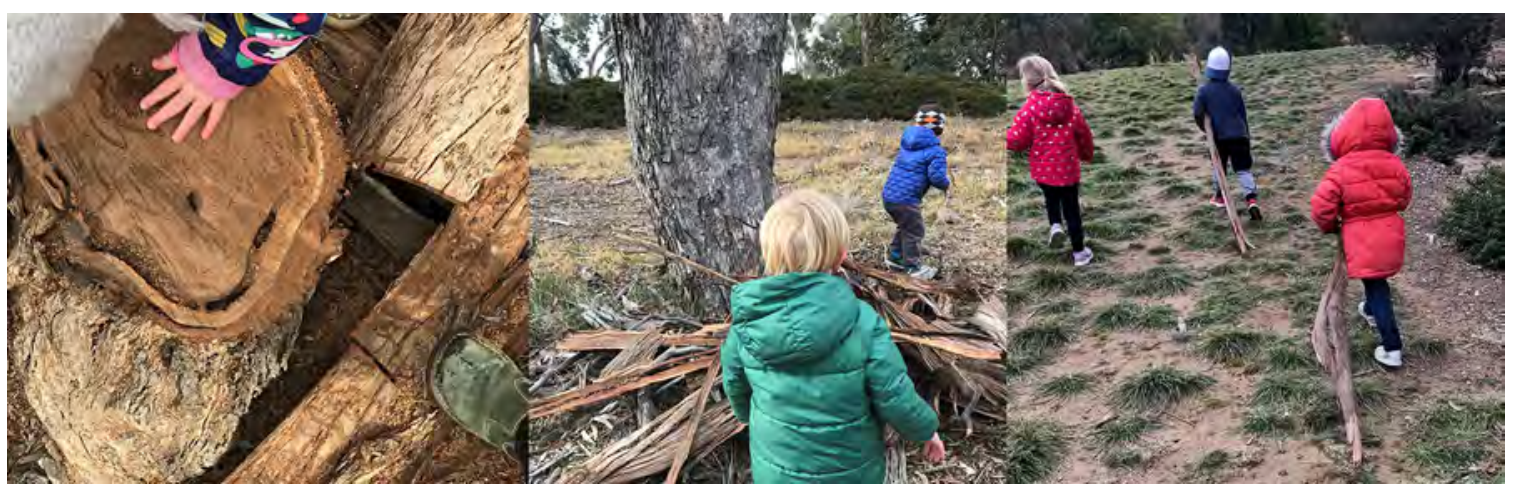

Figure 2: Findingbones. Photo credit: Authors.

\section{Wonderings on Histories Weathered with Human-Machine Encounters}

Circles on the freshly cut surface of a tree reveal years of weathered histories: rainfall, sunshine, drought, living and dying. Powdery sawdust and crisp eucalyptus scent bring children closer. Children wonder who felled the tree and why. Critters are crawling and marks in the trunk are a reminder that insects too are weathering with trees. Bark wanders with children. It is carried and placed to protect other trees from the chainsaws. Bark is a wandering companion. Times, places, imaginings and weathers weave together.

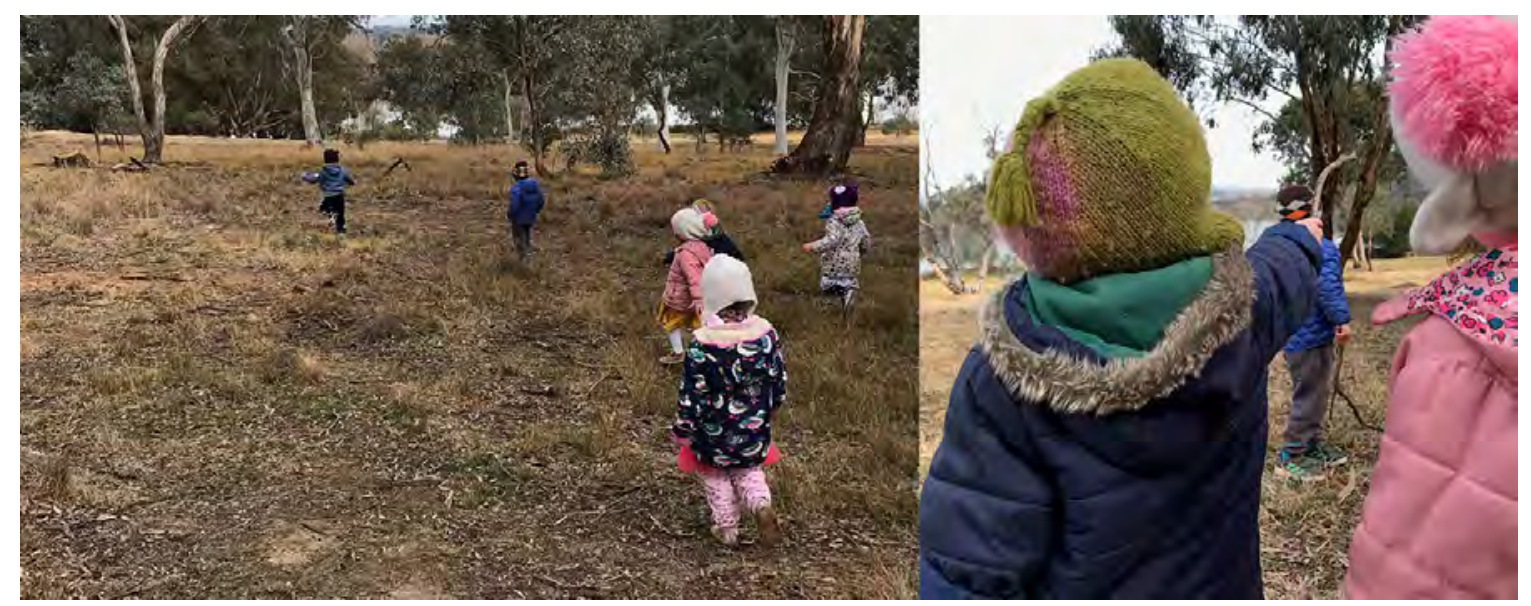

Figure 3: Touchingbark. Photo credit: Authors.

\section{Wonderings with Weather}

These and many other weather encounters feature in our wanderings. Children also look up and wonder at the lines in the clouds: 'wind, monster claws or airplane?' they muse. They imagine weather clouds swirling inside their bodies. They wonder at the fate of a dead rabbit we stumble across, partly decayed and weathered on the ground. "Did she die of cold, or just get sick and old?" "Or did a fox get her?" As we wander with weather, curious weather worlds are opened and we come to know this place and others differently. 


\section{References}

Blaise, M. (2010). Creating a postdevelopmental logic for mapping gender and sexuality in early childhood. In S. Edwards \& L. Brooker (Eds.), Engaging play (pp. 80-95). Buckingham, England: Open University Press.

Blaise, M. (2017). Walking-with the more-than-human: Bodies in the making [blog post]. Retrieved from https://walkinglab.org/category/residencies/

Blaise, M., \& Hamm, C. (2019). Shimmering: Animating multispecies relations with Wurundjeri Country. In D. Hodgins (Ed.), Feminist research for 21st century childhoods: Common world methods (pp. 93-100). London, UK: Bloomsbury.

Blaise, M., \& Rooney, T. (2019). Listening to and telling a rush of unruly natureculture gender stories. In F. Nxumalo and C. Brown (Eds.), Disrupting and countering deficits in early childhood education (pp. 134-146). New York, NY: Routledge.

Ingold, T (2015). The life of lines. Oxon, UK: Routledge.

Latour, B. (2004). Politics of nature: How to bring the sciences into democracy. Cambridge, MA: Harvard University Press.

Neimanis, A., \& Walker, R. (2014). Weathering: Climate change and the "thick time" of transcorporeality. Hypatia, 29(3), 558-575. DOI:10.1111/hypa.12064

Rooney, T. (2018). Weather worlding: Learning with the elements in early childhood. Environmental Education Research, 24(1), 1-12. DOI: 10.1080/13504622.2016.1217398

Rooney, T. (2019). Weathering time: Walking with young children in a changing climate. Children's Geographies, 17(2), 177-189. DOI: 10.1080/14733285.2018.1474172

Springgay, S., \& Truman, S. E. (2018). Walking methodologies in a more-than-human world: WalkingLab. New York, NY: Routledge.

Springgay, S., \& Truman, S. E. (2019). Counterfuturisms and speculative temporalities: Walking research-creation in schools. International Journal of Qualitative Studies in Education, 32(6), 547-559.

Stengers, I. (2015). In catastrophic times: Resisting the coming barbarism. Milton Keynes, UK: Open Humanities Press in collaboration with meson press, Hybrid Publishing Lab, Leuphana University of Lüneberg.

Stengers, I. (2018). Another science is possible: A manifesto for slow science. Medford, MA: Polity Press.

Taylor, A. (2013). Reconfiguring the natures of childhood. London, UK: Routledge.

Taylor, A., \& Rooney, T. (2016). 'Walking with wildlife in wild weather times: A common world childhoods research collective blog' [blog post]. Retrieved from https://walkingwildlifewildweather.com/ 
Mindy Blaise is a Vice Chancellor's Professorial Research Fellow at Edith Cowan University, Western Australia. She is a co-founder of the Common Worlds Research Collective and Feminist Educators Against Sexism - \#FEAS. She is currently conducting a multispecies and affect-focused inquiry on children's relations with water, waste and weather. Her postdevelopmental and postfoundational research sets out to trouble the cognitive imperialism of early childhood education.

Tonya Rooney is a lecturer in early childhood at the Australian Catholic University. Tonya's research focuses on children's relations with space, time and more-than-human worlds in contemporary society, and more recently looks to the scenario of Anthropogenic climate change, and what this means for young children's lives and futures. Tonya is currently undertaking research in the field of early years environmental education, with an emphasis on ethnographic walking methods and children's relations with the weather.

Jo Pollitt is an interdisciplinary artist and Postdoctoral Research Fellow at Edith Cowan University. Her work is grounded in a twenty-year practice of working with improvisation as methodology across multiple performed, choreographic and publishing platforms including BIG Kids Magazine. Her current research is invested in interdisciplinary methods of expanded embodiment and creative response in researching children's relations with climate futures. 